Review

\title{
Green and Sustainable Public Procurement-An Instrument for Nudging Consumer Behavior. A Case Study on Romanian Green Public Agriculture across Different Sectors of Activity
}

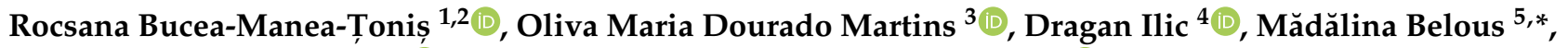 \\ Radu Bucea-Manea-T,oniș ${ }^{6}{ }^{\mathbb{D}}$, Cezar Braicu ${ }^{6}$ and Violeta-Elena Simion ${ }^{5} \mathbb{C}$ \\ 1 Department of Economic Sciences, Spiru Haret University, 030167 Bucharest, Romania; \\ rocsense39@yahoo.com \\ 2 Doctoral School, University of Physical Education \& Sports, C.P. 060057 Bucharest, Romania \\ 3 Instituto Politécnico de Bragança, 5300-253 Bragança, Portugal; oliva.martins@ipb.pt \\ 4 Faculty of Economics and Engineering Management, University Business Academy, 21000 Novi Sad, Serbia; \\ prof.dragan.ilic@gmail.com \\ 5 Faculty of Veterinary Medicine, Spiru Haret University, 030045 Bucharest, Romania; \\ ushmv_simion.violeta@spiruharet.ro \\ 6 Faculty of Economic Sciences, Hyperion University, 030615 Bucharest, Romania; \\ radub_m@yahoo.com (R.B.-M.-T,.); cezar_braicu@hotmail.com (C.B.) \\ * Correspondence: madalina.belous@spiruharet.ro; Tel.: +40-722-306-189
}

\section{check for}

updates

Citation: Bucea-Manea-Țoniș, R.; Dourado Martins, O.M.; Ilic, D.; Belous, M.; Bucea-Manea-Țoniș, R.; Braicu, C.; Simion, V. Green and Sustainable Public Procurement-An Instrument for Nudging Consumer Behavior. A Case Study on Romanian Green Public Agriculture across Different Sectors of Activity. Sustainability 2021, 13, 12. https://dx.doi.org/10. 3390/su13010012

Received: 16 November 2020 Accepted: 18 December 2020 Published: 22 December 2020

Publisher's Note: MDPI stays neutral with regard to jurisdictional claims in published maps and institutional affiliations.

Copyright: () 2020 by the authors. Licensee MDPI, Basel, Switzerland. This article is an open access article distributed under the terms and conditions of the Creative Commons Attribution (CC BY) license (https: / / creativecommons.org/ licenses/by/4.0/).

\begin{abstract}
Green Public Procurement (GPP) became an efficient instrument to achieve the objectives of environmental policy expressed by the European Commission in its Communications. At the same time, it must be addressed by the public authorities as a complex process, in which all purchased goods and services must integrate perfectly into an entire puzzle-like system of legislation, the construction field, innovation, healthcare, food, and education. Scientific references published in the Web of Science (WoS) mainly between 2017 and 2020 were investigated, and they analyze the implications of green public procurement in various fields, as presented by scientific communities. This article brings as a novelty in this context the identification of some barriers in the adoption of these processes, so that they can be overcome. Based on good practices and international standards and trends, the article shows how aspects related to the implementation of green procurement in society can be taken into account. In the second stage, we added a case study on Romanian green agriculture and discussions regarding inter-correlation between different fields and GPP.
\end{abstract}

Keywords: sustainable public procurement (SPP); green public procurement (GPP); consumer behavior; sustainability; GPP barriers; green Romanian agriculture

\section{Introduction}

The procurement of goods, services, and works, in particular green public procurement (GPP), must be done with as little impact on the environment as possible. Moreover, Roehrich shows in a study that green supply chain management (GSCM) should exist before moving to procurement [1]. There is a need for permanent information on suppliers and finding the best short-term solutions with long-term impacts [1]. Furthermore, Circular Supply Chain Management (CSCM) offers a new and compelling perspective on the field of supply chain sustainability. Farooque et al. identifies a number of important directions that are not sufficiently covered and require further study in the future [2]. Of these, the collaboration in the supply chain and factors and barriers of CSCM are the ones we considered important [2].

GPP, at the same time, is an indicator of the "CE monitoring framework" for a circular economy [3-5]. Other indicators were identified: self-sufficiency for raw materials; waste 
generation; food waste; recycling rates; recycling/recovery for specific waste streams; contribution of recycled materials to raw materials demand; trade-in recyclable raw materials; private investments, jobs, and gross value added. In line with the European Commission's clarifications on green and sustainable public procurement, many EU public authorities are implementing GPP as part of a broader approach to sustainability in their procurement. This process also addresses economic and social issues [6]. However, it is not the policy objectives that are changing; tools and techniques are those that change, including in the procurement system where [6] points out that the awarding of public procurement contracts, having as an award criterion the social aspects, was an important objective for the integration in a bigger market. These possibilities need to be considered in the future; economic crises can bring major changes-they can be a boost or budgetary constraints can change direction [7].

The European Commission considers that Sustainable Public Procurement (SPP) is [8] a method used by public authorities to accomplish the best equilibrium between economic, social, and environmental pillars of sustainable development, during the different stages of procuring goods, services, or works [6]. Thus, SPP implementation consists of six different aspects: Green Public Procurement (GPP), Internal Social Criteria (ISC), Social Return on Investment (SROI), Bio-based Public Procurement (BPP), Circular Economy (CE), and Innovation-oriented Public Procurement (IPP). There were designs including specific toolboxes for supporting SPP, including practices, management, and inter-organizational dimensions [8].

The market experience-a survey on public procurers in Holland [8] on the importance of knowledge and competencies, skills in SPP, affective engagement to SPP, and organizational education and information capacity regarding SPP types-proved that they are generally good abilities for an organization to hold/own, but that they otherwise do not have a direct positive effect on GPP. The knowledge background regarding sustainability has a positive impact on implementing GPP. Organization operationalized as affective commitment did affect GPP, but none of the other types of SPP. Organizational learning capacity influenced most types of SPP, IPP, GPP, and CIE. In conclusion competencies, skills, motivation, and convenience influence GPP but not all aspects of SPP [9].

\section{Theoretical Framework}

GPP can potentially be a very effective tool to develop environmental policies for creating competitive advantage when costs are reduced and, most importantly, resulting in positive environmental impacts. Environmental considerations that are rarely applied in public procurement can be effective and must be included in the technical specifications, award criteria, and performance clauses of the GPP contract. Contract performance clauses may also be used by public contracting entities to introduce environmental considerations into the procurement process. The lack of adequate regulations at national level and the lack of trained staff in this field may be some of the causes of failure of GPP implementation [10]. Improving the technical knowledge, building capacity of the procurement workforce and the knowledge and competences of the procurement officials on the matter will facilitate the implementation of GPP with a positive impact on the environment [11].

Environmental policy instruments, such as GPP, should be focused on the impacts of implementation, but also evaluate the efficiency of the instrument. This can be assessed on the basis of cost and achievement of objectives, and its long-term value-added potential. The state has to nudge the eco-innovation through GPP to achieve SPP. [12] According to [13], after a systematic review ( 80 practices identified by the European Union and implemented by governments in 80 countries) GPP practices are based on several dimensions: geographical origin, government capacity to implement, criteria used for implementation as the period in which this is done, and the impact of these practices on the environment but also on the economy. According to the authors, in order to reduce costs and technical complexities, the tender can be divided into sections and thus integrate demand from small 
buyers extending the participation to small suppliers. Aiming SPP, GPP can develop a joint procurement of small Governments [13].

While seeking positive economic results, particularly in the short term, productive activities pay less attention to the common interest or the environment. Due to its short-term objectives, this productive methodology has not realized the importance of people and the environment for the future of activities and our planet. Good practices for sustainable development are crucial. Moreover, urban sustainability, food, healthcare, and education were considered some important areas in terms of the sustainability of the consumer's behavior. It is necessary to change the way we think and use an integrated approach to discover what it means to produce, process, deliver, use, and especially recover and regenerate products [14]. In our research, we chose the most recent research work (2017-2020), although important previous references were thus excluded so as to highlight the trend in research in this field.

At the same time, we aimed to fill the gap regarding the transition from GPP to SPP, focusing on urban sustainability in building design and construction, trend in food consumer behavior for a sustainable environment, healthcare services, good practices in education for sustainable development, GPP innovation and its influence on consumer behavior and especially green public procurement applied in organic agriculture in Romania. Table 1 presents a general description of the GPP applied in organic agriculture in Romania.

Table 1. Green public procurement (GPP) applied in organic agriculture with a focus on Romania.

\begin{tabular}{|c|c|}
\hline Dimension & GPP Applied in Organic Agriculture \\
\hline $\begin{array}{l}\text { Supply chain management } \\
\text { (SCM); Circular economy } \\
\text { (CE) }\end{array}$ & $\begin{array}{l}\text { SCM is a crucial element in the approach of nudging consumer } \\
\text { behavior to SPP, as an information tool to find the best supplier } \\
\text { and the best short-term solutions with long-term impact. Circular } \\
\text { Supply Chain Management is even more important because } \\
\text { provide information on green raw materials, food waste, trade-in } \\
\text { recyclable raw materials, etc. [1-4] }\end{array}$ \\
\hline $\begin{array}{c}\text { GPP across different } \\
\text { sectors }\end{array}$ & $\begin{array}{l}\text { GPP is studied as a tool in the EC approach of meeting Green } \\
\text { Deal objectives. GPP applied in different sectors of activity has a } \\
\text { positive influence on organic agriculture. Regarding organic } \\
\text { agriculture in Romania, we have identified two gaps: constant } \\
\text { failure to support this topic through research and more scientific } \\
\text { references in this field and the need to implement measures to } \\
\text { ensure sustainability. As noted in the presentation of the case } \\
\text { study, some government measures (e.g., subsidies) have had a } \\
\text { positive impact on the development of this sector. Our research } \\
\text { highlights the problems in the organic agriculture sector of the } \\
\text { Romanian economy. It shows that profit losses for farmers can be } \\
\text { minimized but also the need to implement green measures in the } \\
\text { context. The study can contribute to taking measures on } \\
\text { continuous review and completion of national legislation in this } \\
\text { field; consumer information campaigns about organic food, } \\
\text { maintaining the health of the population; promotion in schools } \\
\text { through education programs in the field of organic agriculture; } \\
\text { developing scientific research so as to provide green solutions to } \\
\text { different sectors of activity [5-16] }\end{array}$ \\
\hline
\end{tabular}


Table 1. Cont.

\begin{tabular}{cc}
\hline Dimension & GPP Applied in Organic Agriculture \\
\hline Agricultural production combines best environmental practices, \\
maintains biodiversity, and contributes to the conservation of \\
natural resources, supporting animal husbandry and welfare. \\
The gap in this field has been identified in the measures by which \\
agriculture can comply and respects consumers' preferences for \\
healthy products. Ecolabels are seen as a legitimate tool to \\
mitigate the consequences in the public procurement supply \\
chain for the entire life of the cycle of product development \\
(resource acquisition, manufacture, packaging, \\
and transportation, use, end-of-life) [17-33]
\end{tabular}

In the healthcare sector, there are important concerns regarding green policies and procurement, the impact of products on the environment, inconsistent organizational strategies on GPP,

The impact of GPP on Healthcare Services a high value of cost/benefits balance of green products inefficient supplier value-chain, governmental law and nudges on GPP [34-40]

\begin{tabular}{|c|c|}
\hline $\begin{array}{l}\text { GPP Innovation and its } \\
\text { Influence on Consumer } \\
\text { Behavior }\end{array}$ & $\begin{array}{l}\text { Government agencies use GPP as a tool to nudge eco purchasing } \\
\text { to avoid waste and pollution. They offer detailed information on } \\
\text { price, performance, and other criteria for products, services, } \\
\text { and raw materials. They facilitate environmental innovation that } \\
\text { reduces environmental pressure. Eco-labels are efficient tools for } \\
\text { nudging green consumer behavior, based on environmental or } \\
\text { non-environmental primary GPP standards for "off-the-shelf" } \\
\text { raw material or services [41-58] }\end{array}$ \\
\hline $\begin{array}{l}\text { Urban Sustainability; } \\
\text { Building Design and } \\
\text { Construction }\end{array}$ & $\begin{array}{c}\text { Ecological construction materials are usually associated with } \\
\text { innovation in manufacturing processes having incenting GPP } \\
\text { with positive effects on a sustainable environment. GPP facilitates } \\
\text { sustainable infrastructure for the agri-food sector (e.g., in rooftop } \\
\text { farming) [59-66] }\end{array}$ \\
\hline $\begin{array}{l}\text { Good Practices in } \\
\text { Education for Sustainable } \\
\text { Development }\end{array}$ & $\begin{array}{l}\text { SPP within the education sector and the staff and academic } \\
\text { behavior regarding GPP represents a good example for the next } \\
\text { generations and important drivers for sustainable professional, } \\
\text { economic, and ethical concerns [67-71] }\end{array}$ \\
\hline Barriers & $\begin{array}{l}\text { The principal barriers related to GPP and SPP refer to unused } \\
\text { land, insufficient energy, and an inappropriate transportation } \\
\text { system. They are manifested as a need to adapt the governance } \\
\text { challenges and create an equidistant balance between } \\
\text { socio-environmental and social cohesion aspects, for surpassing } \\
\text { the dysfunctionality in the sustainability ecosystem [72-85] }\end{array}$ \\
\hline
\end{tabular}

After analyzing all the implications of GPP in different sector of activity, we decided to make a case study on Romanian agriculture, starting from data collected from the website of the Ministry of Agriculture and Rural Development regarding dynamics of operators and areas used in organic farming in the period 2010-2019. Thus, we analyzed the extent to which some instruments, such as legislation, supported the implementation of policies in this sector. Public procurement is influenced by regulations and directives, and government legislative reforms are mostly the starting point in guiding them. If this trend continues, they may at some point become better known and anchored in practice. Their analysis and impact can be done on more versatile backgrounds, with the perspective of evolution and maturation in the future [15].

Grandia and Voncken says that "ability, motivation, and opportunity affect GPP but not all types of SPP" [16]. SPP can be achieved mainly through GPP and IPP as a branch of GPP. The center of this research concerns on the relevance of implementing GPP. In this 
regard, we highlighted some barriers that can be found in implementation and suggested a five-step plan that can be done before implementing any change.

\section{Methodology}

Our study with references from the Web of Science (WoS) mainly from 2017 to the present opens interesting perspectives regarding the impact of green public procurement on the future market and research, building an interdisciplinary bridge between science and the economy to reach the target of sustainability. The main topics were public green procurement in construction, food, healthcare sector, education, and the circular economy (waste management).

For the study we used a percolated systematic review of highly quoted literature on GPP impact on sustainability, implementing Preferred Reporting Items for Systematic Reviews and Meta-analysis (PRISMA) guidelines. As criteria, we chose: (i) highly quoted papers, gathered especially from Scopus, and Web of Science databases, (ii) authentic experimental research and review publications, (iii) published between mainly 2017 and 2020, (iv) presented in English, and (v) having as main search term GPP. In our research, we excluded: (i) book chapters and (ii) encyclopedia. Paper percolating was implemented using one of the most performant tools designed to extract and manage articles-Systematic Review Data Repository (SRDR). No institutional ethics approval was launched because the papers were publicly accessible.

In our quantitative research the main topics searched on Scopus and WoS databases, were "GPP in construction", "GPP in healthcare and food", "GPP barriers", "GPP in education", "GPP and circular economy", and "GPP innovation". We selected 80 articles that meet the criteria, with consistent contribution and different content that cover the period 2017-2020 for GPP in different sectors of activity. Although the GPP has already been studied from different perspectives, there is a lot to understand and reflect on, especially if the objective is achieving a Sustainable Public Procurement. In this sense, this research considered unused land, lack of funding, lack of knowledge as the main GGP gap that remains to be explored, especially related to the organic agriculture sector in Romania. Regarding organic farming in Romania, research has not yet been able to provide the necessary support to ensure sustainability. The subsidies have had some positive impacts but there are many problems to be solved. There is a need to implement sustainable measures, and the contribution of this study can help to implement measures and continuously review legislation and promote sustainability.

Thus, the study presents the perspectives and impact of GPP in different fields, such as healthcare and food, innovation, education, etc., that will be detailed in the next sections. The implementation of GPP should be integrated at the same time, in all these sectors, by all the stakeholders, to have a concomitant positive impact on consumer behavior and sustainability.

In the particular situation of the ecological operators in Romania, which we pursued as an objective, we collected and processed data from the official authorities, in order to follow the dynamics and impact of the legislation. The collected data was arranged in tables and descriptive statistics, such as frequencies, mean percentages, and histograms were used for the analysis of variables. In the second stage, we designed a linear regression model that assumes the following: the total area of organic farming is represented especially by cereals and green harvested plants. Organic farming loses a lot of profit because of the uncultivated land. Other cultures (dried legumes and protein crops, tuberous and root plants, industrial crops, vegetables, and permanent crops) have very weak representation. The farmers should use all the land available and plant organic seeds bought through GPP. Our analysis emphasizes inappropriate management in the Romanian agri-food field, due to different factors, but mainly due to lack of funding and knowledge. Here we see the importance of education that represents an important pillar in forming performant managers, that will be able to cultivate the appropriate type of crops following market requests, implementing circular economy principles, and making GPP for the agri-food 
sector. Education has a tight connection with innovation: the interaction between HEIs and innovator economic agents results in a positive impact on the agri-food sector, through IPP tools. Construction fields provide an appropriate infrastructure in agri-food sectors. Thus, the interconnection between different fields creates all the premises for green sustainable agriculture, that will provide healthy ecological food. In the end, the commitment to gain sustainable agriculture will impact positively the population's health. Most of all our article shows that all the fields analyzed have something in common-from GPP to SPP_an instrument for nudging consumer behavior to gain sustainability and a healthy population.

\section{Trend in Food Consumer's Behavior for a Sustainable Environment}

The concept of GPP has been widely recognized in recent years as a useful tool for promoting green products and services and reducing the impact on the environment of the activities of public authorities. Guidelines are provided on procurement for sustainable development not only at the European level (e.g., European Union) but also internationally (e.g., United Nations) [17].

The implementation of GPP by governments as policy instruments is unpredictable in the effect, although it usually aims to increase the purchase of organic food by the public sector and is expected to have a positive effect on increasing the area of organic agricultural land in a country. To achieve that, it is necessary to take into account the high variability of some environmental factors such as climate, soil quality as well as the specificity of the market [18]. The development of these practices is difficult, often impossible, but requires the existence of a general framework and as many good practices as possible specific to the public sector. These practices need an integrated promotion and dissemination mechanism, in the context presented by Elkington's "triple bottom line", a term which states that "business success depends not only on profitability but also on environmental quality and social justice". After 25 years from this statement, in 2019 Elkington made a recall for an adjustment to this term starting from the fact that "... success or failure on sustainability goals cannot be measured only in terms of profit and loss. It must also be measured in terms of the wellbeing of billions of people and the health of our planet, and the sustainability sector's record in moving the needle on those goals has been decidedly mixed. While there have been successes, our climate, water resources, oceans, forests, soils, and biodiversity are all increasingly threatened. It is time to either step up-or to get out of the way." [19]. These three dimensions of sustainable development through economic and social perspectives and environmental impact are also found in the 17 interconnected Sustainable Development Goals (SDGs) of the United Nation's Agenda 2030 [20] and they need to be adopted, implemented, and evaluated continuously, depending on the international, national and regional context. At the same time, they can be included in the general terms of sustainable public procurement (SPP) [21]. Neto (2020) analyzes in a study the current practices regarding public procurement of food and food services in the EU. He analyzes how they cover sustainability aspects by using distinct schemes for food purchase and catering but also sales of equipment in this field. The schemes available to the public in 11 European countries show that approximately 30 different sustainability criteria can be identified and used in procurement schemes. The most important is the environmental criteria where the focus is on two main aspects: the type of food products where the criteria include organic products, seasonality, packaging including the recycling process and fishery products certified following current regulations; secondly, the service acquisition for which the criteria are mainly dedicated to staff training, waste management, menu planning, optimized transport and implementation of an environmental management system. Other aspects follow the source of food products for which the criteria refer mainly to the integrated production and typology of the equipment used for which it is required; for example, that they respect the energy and water efficiency labeling. In addition to environmental issues, other criteria are recommended in the context of GPP, namely ethical criteria (related to animal welfare, for example), social criteria (which meet the 
needs of less developed countries), and health criteria (food safety systems, product traceability, etc.) [5,17].

The literature analyzed also highlights the concept of Food Loss and Waste (FLW) regarding edible products from plants and animals that are lost or not consumed by people. This food still has enough quality to be consumed but is discarded and considered waste because it has no commercial value. It can result from negligence as well as a conscious decision to throw food away. On the one hand, cities offer a huge variety of food. On the other hand, food waste is a huge urban problem in terms of sustainability.

For the twenty-eight member countries of the European Union (EU), FLW has been estimated at eighty-eight million tons in 2012, including inedible waste, which is equivalent to one hundred and seventy-three kilograms of waste per person per year, only in the European Union. Considering that food production was $865 \mathrm{~kg} /$ year, the FLW was approximately twenty percent of the total food produced [22].

The European Commission (EC) is committed to fighting FLW. In terms of impact, the FLW has a huge impingement, namely regarding resource efficiency, consumption, and waste management. These impacts also have some repercussions on the final cost. Furthermore, due to the use of natural resources, such as water and energy, FLW has a large influence on climate change as well. Thus, it is important to rationalize resources, prevent waste, reuse, and recycle materials, in an effort to stimulate the transition from a linear to a circular economy. This approach would drive global competitiveness as well as promoting sustainable growth and development $[23,24]$.

Many international research projects have proven the importance of prioritizing actions for an effective outcome. The FUSIONS Project was a European research endeavor sponsored by the EC that defined a hierarchy of efficient use of resources. This started with prevention at the source and the recovery of edible food, which prioritizes human food over animal feed or reprocessing into non-food products. These extended to recycling resources, energy recovery and conversion, and residue disposal [22]. This hierarchy can result in three dimensions of actions: the first one would be in the sphere of prevention; the last one in monitoring and control the FLW. In the middle are the actions which have the objective to reduce it.

To mitigate the problem, the objective to combat FLW should be based on prevention first. When that is not possible, the cities should look towards its reduction. Finally, the only thing that remains is to monitor and try to control waste. Several initiatives have been taken in recent years to prevent food waste (e.g., a multi-stakeholder platform dedicated to food loss and waste prevention, a food waste prevention calculator, based on life cycle thinking), but evaluation methods for prevention are still needed to identify the best practices [25]. Prevention is one of the important issues [26-28]. It is part of the new circular economy package, which aims to promote sustainable consumption patterns, mainly in restaurants, catering, and households. During the purchase, the consumer can reduce the amount expended to prevent FLW [29].

Reducing can be explored by better plans on the production, processing, and manufacturing, as well as on the distribution chain. Less impulsive buying and consumption behaviors can also reduce FLW. The motivating factors for preventing or reducing FLW refer to voluntary behavior. In this sense, the individual should take small steps to decrease waste. It is a predictive ability that can be described in terms of solving problems. Regarding voluntary behavior, motivation is the keyword for FLW reduction [30]. The conceptual framework combines explicit or conscious factors related to opportunities, with implicit or unconscious factors, mainly related to motivations [31].

The evidence showed that FLW occurs along the entire food supply chain. At this level of waste, since the data already collected by Eurostat has been recognized as manifestly insufficient, it is crucial to develop quantitative and qualitative data monitoring actions, in parallel with other actions to reduce or prevent waste [22]. Finally, at the monitoring level, FLW assumes high values within the EU as well as in other developed countries. To control FLW, the EU approved a common methodology for all members which intends 
to measure FLW. Unfortunately, it has not yet been initiated [32]. Romania agreed with the methodology but was not able to implement it.

The whole economy is tied to the intensification of consumption, which can increase waste. The main paradigm is between higher consumption and preserving the environment. However, rationalizing resources and implementing environmentally friendly practices are fundamental complementary attitudes for achieving long-term sustainability. The current generation must be concerned with leaving a better planet. At least, this generation would maintain the same level of well-being for future generations. Recovery, reduction, recycling, and reuse are needed for environmental sustainability and human survival [33].

\section{The Impact of GPP on Healthcare Services}

In the healthcare sector, there are some challenges frequently manifested in the process of implementing GPP (Figure 1).

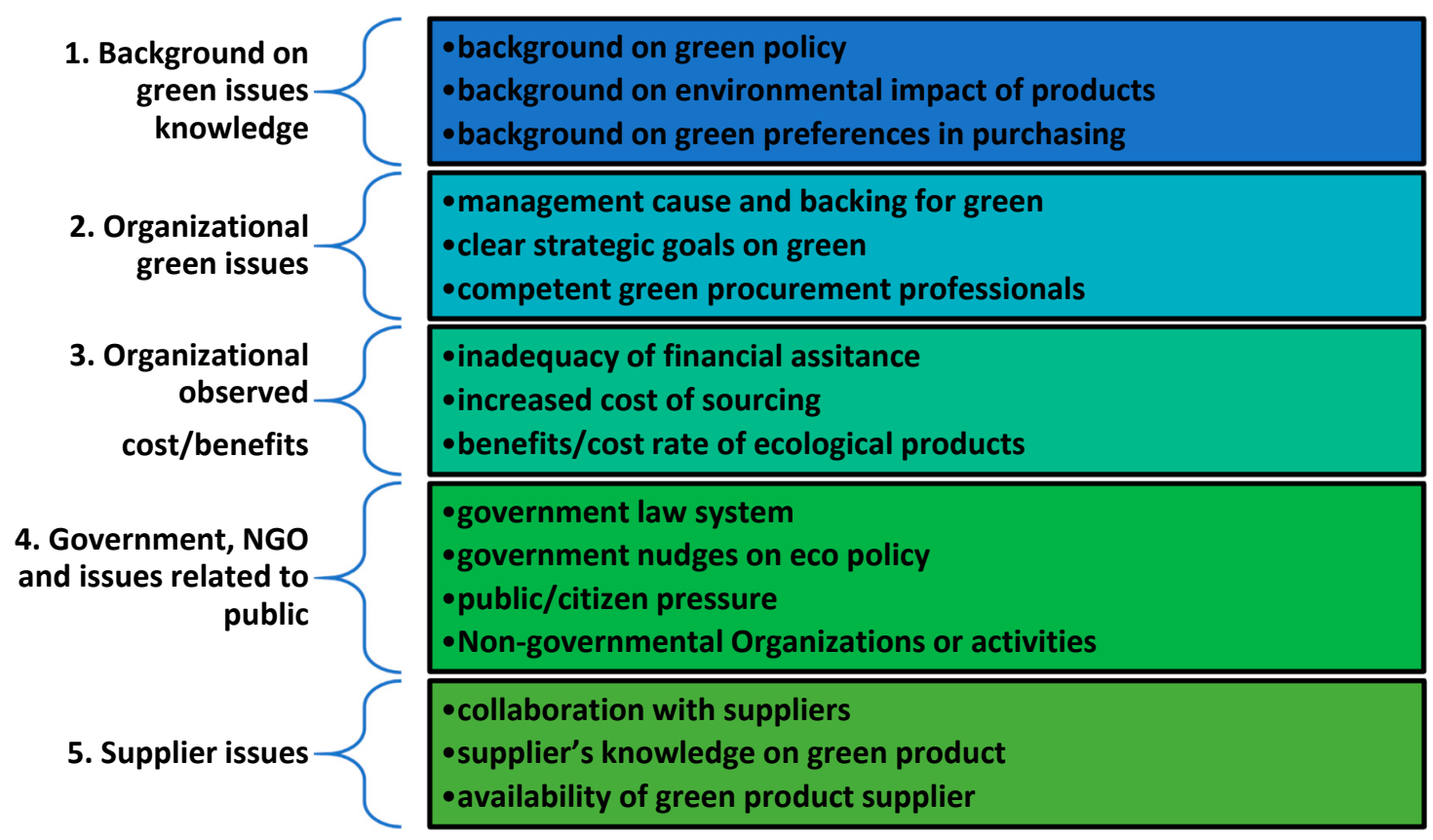

Figure 1. GPP challenges in the healthcare field (Source: adaptation after Ahsan, 2017, [34]).

These challenges have specific manifestations in different countries.

For example, in Australia, the highest concerns are related to insufficient legislation on GPP, management, and backing for green projects, GPP government nudges, and inefficient financial assistance. They have a solid background in ecological issues knowledge and supplier issues. If the GPP strategic challenges are overpassed, the decision-making process and operational implementations are easy to be assured in the Australian health sector [34].

In the UK and Italy, GPP in the health sector has an important weight and a positive effect on return on investment (ROI) for the public purse. Supplier issues register improvement in the green performance area. In the UK GPP has become a cultural standard implemented voluntarily, while in Italy the regulations on green performances and safety have impacted societal (consumer and organizational) behaviors. The worth of green products (the cost/benefit balance of green products and services) seem to be an important challenge in these countries, especially the carbon footprint that local stakeholders try to mitigate as to gain a trustful brand, on one side, and the ethical concerns, on the other side [34]. Regarding packaging, UK organizations prefer to adopt their GPP national standards (ISO 26000, SA8000, and AA1000). Social requirements for suppliers (child labor, forced labor, discrimination, and freedom of association) are implemented on GPP international standards for both Italy and the UK. They focus on the good implementation 
of the ISO 50001 standard on energy administration and household gas mitigation [35]. In Romania, this field is sub-represented.

GPP innovation has an ethical and social purpose and a systemic impact on healthcare. Thus, procurement offices have been established with the aim of intermediating devices for brand evaluation to design criteria on purchasing conditions and measures to control markets over time. GPP innovation is not dependent on R\&D intensive technological change, [36], but a result of market procurement processes that raise sectorial goals [37]. The procurement offices frequently use the instrument of "total costs" for evaluation and budgeting the green life cycle impacts and to expose the conflicts between objectives on special domains and social innovation [37]. Unfortunately, the procurement offices might not have authority regarding innovation opportunities for the "high tech" medical products, as they have in consumables and non-clinical products [38]. In some cases, the lowest cost green product, which will bring short-term cost savings, is not the best solution for the long term, neither financially nor from a healthcare perspective $[39,40]$. Thus, procurement offices should include specialists in different healthcare sectors to advise on long-term alignment in their procurement.

\section{GPP Innovation and Its Influence on Consumer Behavior across Different Countries}

GPP is an investment process based on public policy to answer consumer needs for services, goods, utilities, and works, boosting their advantages as well as impacting the whole world by protecting the environment at the same time. To avoid waste and pollution, governmental programs have been designed concerning environmental consequences when deciding on eco purchasing. These programs evaluate price, performance, and other criteria for products, services, raw materials [41]. Sustainable procurement, implicitly GPP, is one of the goals of The United Nations 2030 Agenda for Sustainable Development. In this regard, the European Commission's Green Public Procurement action established as objective the enhancement in the environmental, energy, and social achievements of products and services through innovative developments [42].

IPP is increasingly contributing to sustainability through its aim in nudging the uptake of EI (environmental innovation) having an impact on regulatory push-pull instruments for decarbonization. This role was confirmed by literature: EI reduces the environmental pressure [39], but the innovative procurement models are different for each procurement context and different types of goods, raw materials, and services. In each context, the experience of procurement managers is decisive [43]. Organizational performance is in direct positive correlation with internal environmental involvement, supplier cooperation, customer requests, competitive challenges, and management support. Thus, GPP is correlated with firm performance [44,45].

In GPP, innovation appears as a process, service, and policy [46]: in the GPP process, in public services employing GPP, and in the use of GPP as an instrument for demand-side sustainable policymaking. GPP is used as part of innovation policy and new strategies and models that are used in value creation through PP. At the same time, IT support is used for PP. GPP brings new management challenges in out-of-the-box acquisitions of innovation, involving technical knowledge, accurate information, insight overview, and funding resources. GPP is important in the innovation cycle, such as R\&D management, commercialization, and project and risk management [46].

Green Supply Chain Management (GSCM) will overpass barriers in reducing waste, facing competitiveness through innovative strategies (e.g., in green logistics and green procurement), reducing carbon dioxide emissions (due to replacement of fossil fuels with alternative fuels) and reducing operating costs. GSCM is an instrument to nudge GPP and gain sustainability and fulfilling Green Deals objectives [47].

Eco-labels are designed for environmental or non-environmental primary standards of information when a company does GPP for "off-the-shelf" raw material or services. Other important standards refer to layers of environmental performance, conception, configuration, and security. The most common criteria for a contract to be awarded are envi- 
ronmental characteristics measured by "most economically advantageous tender" (MEAT), which include environmental life-cycle costing. Environmental criteria are required for all participating companies in order to implement an eligible project [48].

Ecolabels are seen as a legitimate tool to mitigate the consequences in the public procurement supply chain for the entire life cycle of product development (resource acquisition, manufacture, packaging, and transportation, use, end-of-life). They are included in the international standard (ISO 20400) regarding sustainable acquisitions. ISO 20400 is an important landmark for sustainable procurement for any organization. It promotes standardized guidance for all different stakeholders involved in internal and external PP, irrespective of whether they are contractors, consumers, suppliers, or local authorities. Sustainability regulations and ecolabels and certifications are methods to verify the sustainability of supply chain consequences regarding being appropriate for the objective, health social, environmental, or ethical issues [48-50]. In Romania, more and more organic crops have appeared in recent years and the green labeling system has started. Special stands have been created in stores for eco products, but the efforts are big, and the results are shy.

The expected benefits of applying this standard into PP are more adequate management practices, differentiation between the programs that sustain environmental, human rights, or ethical issues, and encouraging the launch of similar programs [51,52]. A very complex standard is Good Environmental Choice Australia (GECA). It contains 19 standards ranging from different fields. GECA standard requirements [52] are (Figure 2):

\section{Appropriate for aim (similar with Australian or international standards)}

\section{Raw material demens (reserve extraction issues and productivity)}

\section{Emissions}

\section{Hazardous \& prohibited materials}

\section{Energy management}

\section{Water management}

\section{Waste management}

\section{End of life (recycling, packaging, product labelling \& product stewardship)}

\section{Environmental claims (ISO 14021)}

\section{Environmental and other issues}

Figure 2. Good Environmental Choice Australia (GECA) standard requirements (Source. Adaptation Ecolabel Index, 2020 [52]).

When a company does pure basic research, idea exploration, or design a solution it substantiates its activity on a standards inventory. Then the company does basic research, a prototype, and/or applied research. In this phase, the company substantiates its activity on terminology standards. Before commercialization, the company applies measurement and testing standards for experimental development and scale-up. Government involvement in standardization and key market providers' standards adoption is very important in the initial stages of life crisis $[53,54]$. Public procurement supports the development of innovation markets through the facilitation of the expression of new demand, creating a demand, improving the innovation environment, increasing reciprocal collaboration be- 
tween suppliers' and users' knowledge, facilitation of co-adaptation and bilateral learning, and providing information and incentives [55,56].

In Germany, Public Procurement with Contracted Innovation (PPCI) facilitates incremental innovations, but not market novelties, because there is an insufficient stimulus for radical innovations. Thus, the dissemination of new technologies is facilitated, to the disadvantage of radical inventions [57]. Pollution management, innovations in the ecosystem services supply, innovation in eco-procurement, transportation, and greening of guests are decisive factors in establishing a cleaner eco-environment and ecological industry [58].

\section{Urban Sustainability in Building Design and Construction}

Urban sustainability is a subject of interesting debates in articles within the construction field [59] such as designing a novel procurement scheme for converting empty houses through sustainable methods with governmental funds and thus avoiding multiple deprivations. The positive impact on the sustainable economy is the increase of economic attractiveness for financing, reducing unemployment, reducing the number of families with small salaries, mitigating their addiction to social benefit, and mitigating crime rates, better health, better educational fulfillment, the increased claim for workers, reducing community breakdown, good presence in civic activities and good public services [60]. Reducing the number of empty homes will ameliorate the symptoms above [59]. Building eco-houses and sustainable renovation of empty houses help the development of eco-cities through $\mathrm{CO}_{2}$ emissions reduction, mitigating the pressure on the greenfield development, addressing sustainable policies, such as the zero-VAT policy for new construction (reduced rate of 5\%), Renewable Heat Incentive (RHI) and Feed-in Tariffs (FITs) schemes. The beneficiaries of the financial incentives are the owners (the house occupants) for the implementation of sustainable technology [60,61]. Digital technologies seem to be an incentive for the property development field, stimulating sustainable urban consumer behavior [61]. The reduction in house maintenance costs could increase the disposable income available for purchasing green and sustainable food and adopting healthier practices.

Other sources for urban sustainability are raw materials (concrete, steel, wood, glass, etc.), products used in construction, temperature control equipment, etc. [63]. The lack of an integration framework for the promotion of e-procurement $(\mathrm{eP})$ and sustainable procurement (SP) in the construction industry deprives opportunities to optimize the implementation of resources. Yu et al. (2019) propose the development of an integration framework for the promotion of eP and SP in the construction industry [64]. The circular economy principles are met in a sustainable city in all of the building's development and utilization stages: (a) construction materials development process (all the actions needed in production from supply to transport and manufacturing), (b) edifice construction stage (the same actions as in stage a), (c) usage stage (renovation, conservation, energy losses, and restoration) and, (d) end-of-life (clearance and recycling). The utilization stage seems to be more expensive, due to the heating and cooling energy requirement $[60,61,65]$. The operational energy needs may be reduced also by using fossil ammunition or using electricity for lighting, but an important percentage of the energy needs should be reduced by using sustainable building materials. Using green construction materials, we gain a sustainable environment, due to innovative extraction or manufacture processes [66]. These processes mitigate dust emissions and noise during construction and bring important benefits regarding greenhouse emissions. From the one-health perspective, we must highlight the positive effects on the human (occupants) health too [60]. To mitigate the construction impact on the environment, $\mathrm{CE}$ has as a priority the development of detailed GPP criteria for the sector.

The construction sector can provide a sustainable infrastructure for the agri-food sector, especially in rooftop farming and other similar solutions in big, crowded cities. 


\section{Good Practices in Education for Sustainable Development}

A complex study made on HE (higher education) fields-on universities from the UK, Canada, the USA, and Australia - reveals the most frequent GPP categories that universities invest in $[67,68]$. The study reveals that HEIs invest especially in ecologic electricity, paper, office equipment, and food, as might be seen below:

- $\quad$ indoor lighting products and paper for educational purposes $(48 \%)$,

- $\quad$ office IT equipment (e.g., computing and communications machines, used by academic, professional, and administrative staff- $-43 \%$ ),

- $\quad$ food and catering services (e.g., packaged foods and drinks to be sold in the university's cafes and refectories/restaurants, and for preparation and cooking in the university's kitchens-33\%),

- $\quad$ sanitation and washing products or services-34\%,

- disinfectant: general and for removal of insect and rat substances-24\%

- $\quad$ gardening products and services (e.g., electrical/battery and non-electrical items-24\%)

- local and organic food acquisition scheme-24\%

- $\quad$ acquisitions made from eco-friendly and socially responsible organizations-10\%

HEIs (Higher Education Institutions) SPP (Sustainable Public Procurement) behavior is a good example for the next generations. HEIs most important drivers for implementation of a good SPP behavior are [61,62] professional, economic, and ethical concerns:

- HEIs tendency to lead best practice $43 \%$

- Cost savings 39\%

- Moral/ethical motivations 38\%

- Government legislation lawmaking 29\%

- HEI's stakeholder demands and/or expectations $29 \%$

- $\quad$ Expected-anticipated reputational benefits $20 \%$

- $\quad$ Third-party requirements $10 \%$

SP in the educational sector is endorsed by good practices set by HEIs President's and/or Chancellor's Office 58\%, internal regulation management or bottom-up initiatives of HEI employees or students $57 \%$, the awareness of a job well done $52 \%$, ethical and moral concerns of employees $43 \%$, or stakeholder requirements $29 \%$.

In Romania, HEI should have the main aim to sustain innovation and to form professional managers, able to come up with an adequate solution to agri-food management challenges. The urgent need for performant management in resource allocation on the different types of cultures/plantations, based on GPP, in Romania, can be surpassed with the support of HEI graduates.

In HE the adoption and implementation of SPP is well represented, reducing the negative impact the business has on the environment. However, most important is the high awareness and commitment among staff and students regarding SPP, behavior that will be extended on future generations as second nature. Staff and academic behavior regarding Green Public Procurement (GPP) represent good nudges for future generation sustainable consumer behavior $[67,69]$.

HEIs face many barriers in implementing SPP, such as costs ("reducing stress in each division's budget, giving bonuses if the $\mathrm{SP}$ is used as an important factor for the purchase decision"), lack of understanding legislation, lack of skills and knowledge regarding GPP, sometimes lack internal social criteria (ISC), lack of understanding Bio-based Public Procurement (BPP) and Innovation-oriented Public Procurement (IPP). However, in HEIs the Social Return on Investment (SROI) is very evident, because of the academic and students' commitment and awareness regarding GPP [70] and due to the recommendations and research published by academia in journals with high impact. State or stakeholders' incentives in implementing GPP encourage HEIs to overcomes barriers [67,71]. 


\section{Barriers to Sustainability}

The transition of industries in general from linear to circular production is still far from happening. Achieving more sustainable production, distribution, commercialization, and residues management involves the paradigm of consuming versus optimizing resources and preserving the environment. Perhaps, this is one of the greatest barriers to sustainability. Thus, the objective is to organize these barriers in two dimensions: from the offer perspective (supply) and the market view (demand). Furthermore, the identified barriers can be structured according to the resources. The suggestion is to consider tangible and intangible resources. Nevertheless, human resources should be divided between the workforce, which is tangible, and knowledge, mainly tacit, which is intangible. Thus, the first barrier is knowing the specificities of each city to develop a capable model to develop a plan and to implement it, aiming to urban sustainability [72]. Failure to select the right suppliers is the most important risk factor for SCM, as supplier selection plays an important role in achieving social, environmental, and economic benefits [73].

There are five dimensions when tacking about indicators: economic, social, environmental, institutional, and other [71]. In developing countries, critical barriers were related to governmental, human, knowledge and information, market, and cost and risk barriers $[74,75]$. The core of sustainable urban transport indicators is fossil fuel consumption, length of motorway system, the number of vehicles, and HDI. Weak incentive policies, lack of legislation, and insufficient social awareness, the company's unawareness, unmatched vision and culture, insufficient top management commitment and competitors' inaction are the main barriers considered in the photovoltaic industry $[75,76]$.

According to the United Nations (UN), one of the basic barriers is understanding long-term population trends; how they understand how to manage natural resources sustainably, how they will adapt to climate change, and how they will know how to overcome barriers and access markets, financial services, increasing access to information and education $[77,78]$. It is necessary to maximize the benefits of agglomeration and, at the same time, minimize environmental degradation. This barrier is considered the most relevant barrier, namely in low and middle-low income countries, where urbanization occurs more rapidly and without organization. A proper social balance needs to be found [72].

The business model used by companies, which aims for short-term results can be responsible for a lot of carbon dioxide emitted by industries, or diversification of products made from $\mathrm{CO}_{2}$, or using a low technological level or have no concert about the energy source. All those aspects were considered as a factor of influence of urban sustainability, often associated negatively $[79,80]$.

Maybe one of the most important barriers is the prevalence of a dysfunctional sustainability ecosystem [81]. According to the authors, interest groups installed exploit the system only for their benefit. Other barriers were related to the need to adapt to governance challenges. At the same time, the city has to balance socio-environmental and social cohesion aspects when implementing nature-based solutions (NbS) $[82,83]$. This dynamic is complex and difficult to follow. To identify the main barriers to urban sustainability, from the offer (supply) market (demand) views, (supply versus demand), this revision results in an organizational framework. It aims to structure the tangible versus intangible factors. Table 2 below structures only the main barriers related to the consumption paradigm. 
Table 2. Principal barriers related to consumption.

\begin{tabular}{|c|c|c|}
\hline Barriers & Offer & Demand \\
\hline Tangible & Land, energy, and transportation system & $\begin{array}{l}\text { The need for energy and } \\
\text { transportation system } \\
\text { requirement compared to } \\
\text { lifestyle desired }\end{array}$ \\
\hline Intangible & $\begin{array}{l}\text { Need to adapt to governance challenges and } \\
\text { have to balance socio-environmental and } \\
\text { social cohesion aspects }[82,83] \\
\text { The business model used by companies [81] } \\
\text { Dysfunctional sustainability ecosystem [81] }\end{array}$ & $\begin{array}{l}\text { The lifestyle desired } \\
\text { Understanding long-term } \\
\text { population trends [78] } \\
\text { Knowing the specificities of } \\
\text { each city }\end{array}$ \\
\hline
\end{tabular}

In most situations, it is easier to identify the need for tangible resources. Barriers on the supply side are also easier to overcome, especially when compared to barriers on the demand side. On the contrary, as the name says, intangible resources are much more difficult to achieve and overcome. To implement urban sustainability, the practical implication of this framework is the structure to develop a plan [80]. From Table 2, our research suggested a methodology to plan urban sustainability in five steps. Figure 3 shows the sequence of steps.

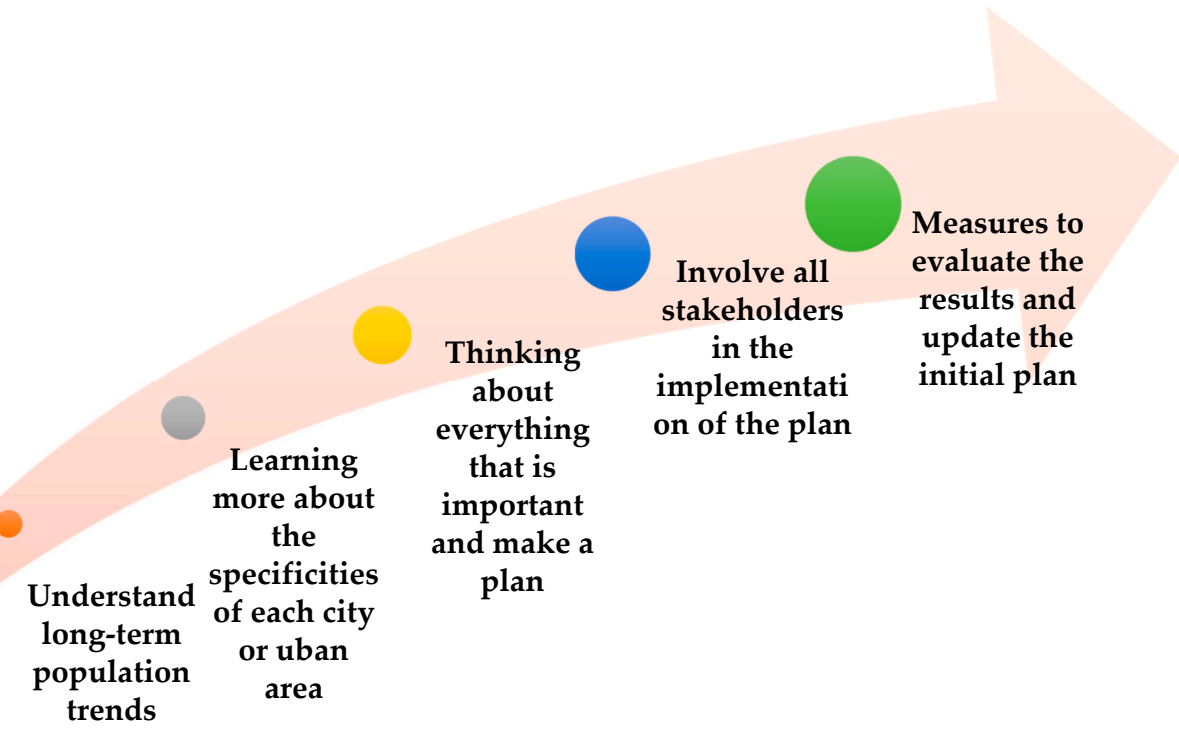

Figure 3. The five steps towards planning sustainability.

In the first step, it is suggested to understand long-term population trends. Following this step, it is suggested to learn more about the specificities of each city or urban area. How they work in terms of transportation and energy, demand and supply structure, and which lifestyle factors are the most significant to that community [66]. In the next step, it is suggested to think about everything important. It is suggested to make a plan before implementing any change. After the implementation, changing anything probably costs more. Finally, the objective should involve different stakeholders. So, it is important to evaluate the results. Perhaps the plan needs to be updated [72].

\section{Green Public Procurement Applied in Organic Agriculture in Romania}

Agricultural subsidy policies are important in the context of public food procurement. In Romania, the "Green public procurement guide" was approved in October 2018. This includes the minimum specification requirements regarding environmental protection for certain groups of products and services for GPP related to product groups and/or priority 
services, including food and catering services [84]. The main purpose of issuing the guide was to provide contracting authorities information on the mandatory minimum requirements to be provided when drafting documentation for the award of GPP contracts for products and services, according to the European Commission's Handbook on Green Public Procurement. These practices come in the context in which in Romania, the dynamics of operators and areas used in organic farming in the period 2010-2019 as provided on the website of the Ministry of Agriculture and Rural Development, show a significant increase in recent years (Figure 4), starting with 2017. These increases were highlighted for the total area allocated to organic farming, cereals, industrial crops, and green harvested plants.

\section{Dinamics of operators and areas in organic farming}

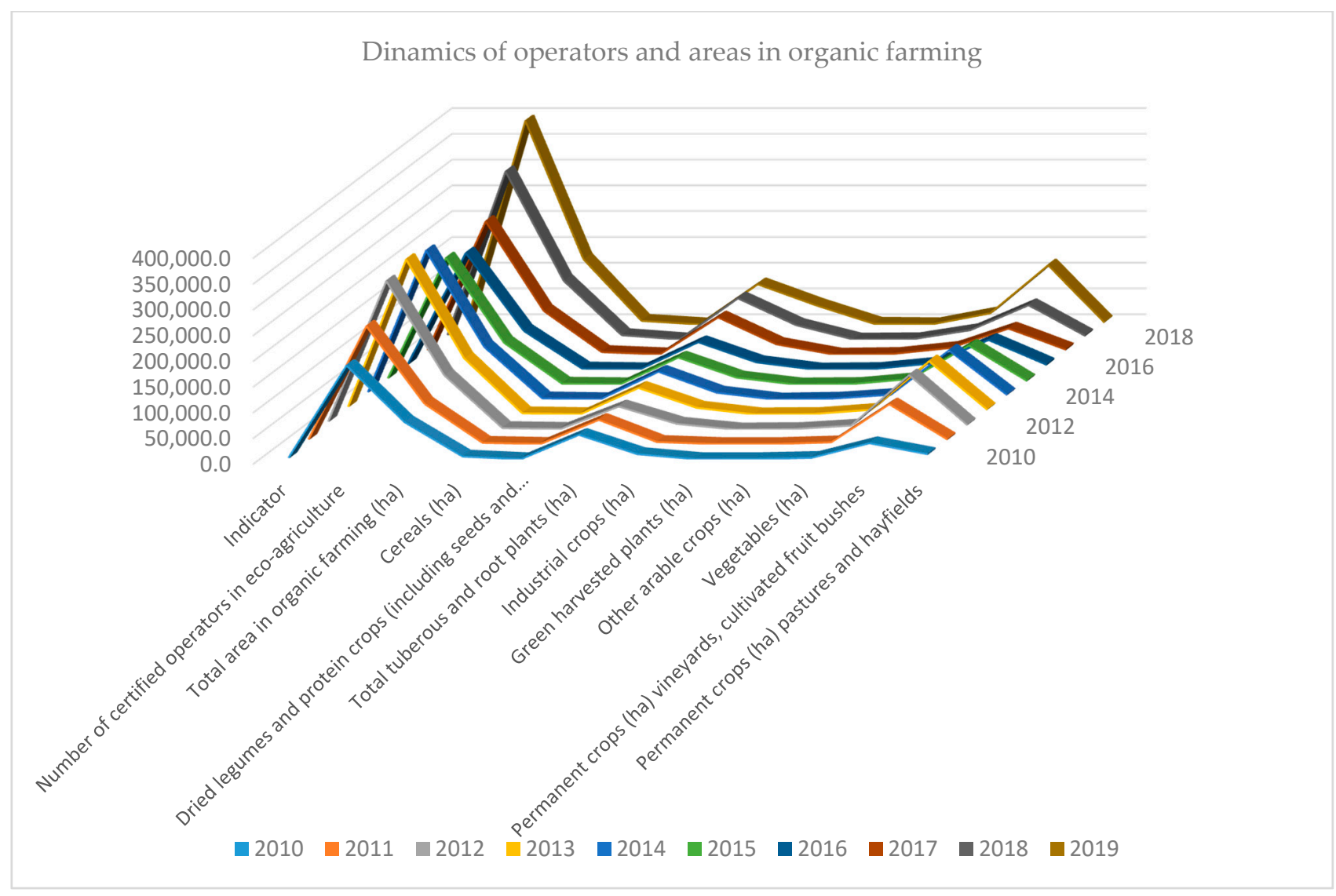

Figure 4. Dynamics of operators and areas in organic farming (Source: data processing following the website of the Ministry of Agriculture and Rural Development) [84].

It can be seen in Figure 4 that there was a peak in 2014, due to subsidies. The nonadaptation to these practices quickly led to a halving of the number of Romanian farmers who practice organic farming in just four years, even though subsidies for these crops have been higher than those for the land surface. The reason is the lack of a market and the strict obligations imposed on these beneficiaries of European subsidies. An important reason is that Romanian farmers do not easily understand or accept the importance of association. Organic vegetables and fruits last much less than those treated chemically, and if producers do not sell them fast enough, they end up as waste. Farmers cannot negotiate with supermarkets or wholesalers individually. They remain with unsold products because they cannot capitalize on their production in the markets. Organic products are more expensive while the purchasing power of the population is low. The best way forward would be to associate and set up agricultural cooperatives that constantly provide fresh goods. The status quo has begun to change in recent years. In 2019, 9821 operators were registered, and the total ecologically certified area was 395,227.97 ha, the largest in the last nine years. In 2018, 9008 operators were registered, the first increase after a significant 
decrease recorded for several years: from 15,544 in 2012 to 8434 in 2017, as specified by the Ministry of Agriculture and Rural Development.

In the second stage of the analysis, we designed a regression model that confirms our conclusion: organic farming is represented especially by cereals and green harvested plants. Organic farming loses a lot of profit because of the uncultivated land. This problem can be surpassed through GPP and IPP managed by Romanian specialists formed by innovative HEIs. The correlation matrix shows a strong positive correlation between the variable Total area in organic farming and Cereals (0.96), Permanent crops (ha) vineyards, cultivated fruit bushes $(0.81)$, and Green harvested plants $(0,80)$. The first conclusion is that most of the organic farming is represented by cereals, permanent crops and Green harvested plants. The second conclusion is that industrial crops are represented by Permanent crops (ha) vineyards, cultivated fruit bushes (0.89), and Dried legumes and protein crops (including seeds and mixtures of cereals and legumes) (0.80).

Our model is significant because the test assumptions are met, and the statistics are relevant. The test assumptions are: our variables are continuous, there is a linear relationship between the independent variables and dependent variables (graphic scatterplot), there are no extreme values, residuals are not correlated (Durbin-Watson coefficient 2214, included in the interval $1.5<\mathrm{d}<2.5$, Table 3 ), the dates demonstrate homoskedasticity and residuals have an approximately normal curve (Figure 5 P-P plot).

Table 3. Model Significance.

\begin{tabular}{|c|c|c|c|c|c|c|c|c|c|c|}
\hline \multicolumn{11}{|c|}{ Model Summary ${ }^{b}$} \\
\hline \multirow[b]{2}{*}{ Model } & \multirow[b]{2}{*}{$\mathbf{R}$} & \multirow{2}{*}{$\begin{array}{l}\mathbf{R} \\
\text { Square }\end{array}$} & \multirow{2}{*}{$\begin{array}{l}\text { Adjusted } \\
\mathbf{R} \\
\text { Square }\end{array}$} & \multirow[b]{2}{*}{$\begin{array}{l}\text { Std. Error of } \\
\text { the Estimate }\end{array}$} & \multicolumn{4}{|c|}{ Change Statistics } & \multirow[b]{2}{*}{$\begin{array}{l}\text { Sig. F } \\
\text { Change }\end{array}$} & \multirow[b]{2}{*}{$\begin{array}{l}\text { Durbin- } \\
\text { Watson }\end{array}$} \\
\hline & & & & & $\begin{array}{l}\text { RSquare } \\
\text { Change }\end{array}$ & F Change & df1 & df2 & & \\
\hline 1 & $0.985^{\mathrm{a}}$ & 0.971 & 0.957 & $12,444.97670$ & 0.971 & 67.256 & 3 & 6 & 0.000 & 2.214 \\
\hline \multicolumn{11}{|c|}{ ANOVA $^{b}$} \\
\hline \multicolumn{2}{|c|}{ Model } & \multicolumn{2}{|c|}{ Sum of Squares } & Df & \multicolumn{2}{|c|}{ Mean Square } & \multicolumn{2}{|l|}{$\mathbf{F}$} & \multicolumn{2}{|l|}{ Sig. } \\
\hline \multirow{3}{*}{1} & Regression & \multicolumn{2}{|c|}{$31,249,080,149.865$} & 3 & \multicolumn{2}{|c|}{$10,416,360,049.955$} & \multicolumn{2}{|l|}{67.256} & \multicolumn{2}{|l|}{$0.000^{\mathrm{a}}$} \\
\hline & Residual & \multicolumn{2}{|c|}{$929,264,670.535$} & 6 & \multicolumn{4}{|c|}{$154,877,445.089$} & & \\
\hline & Total & \multicolumn{2}{|c|}{$32,178,344,820.400$} & 9 & & & & & & \\
\hline
\end{tabular}

a Predictors: (Constant), Uncultivated, Cereals, Green_harvested; ${ }^{\mathrm{b}}$ Dependent Variable: Organic_farm.
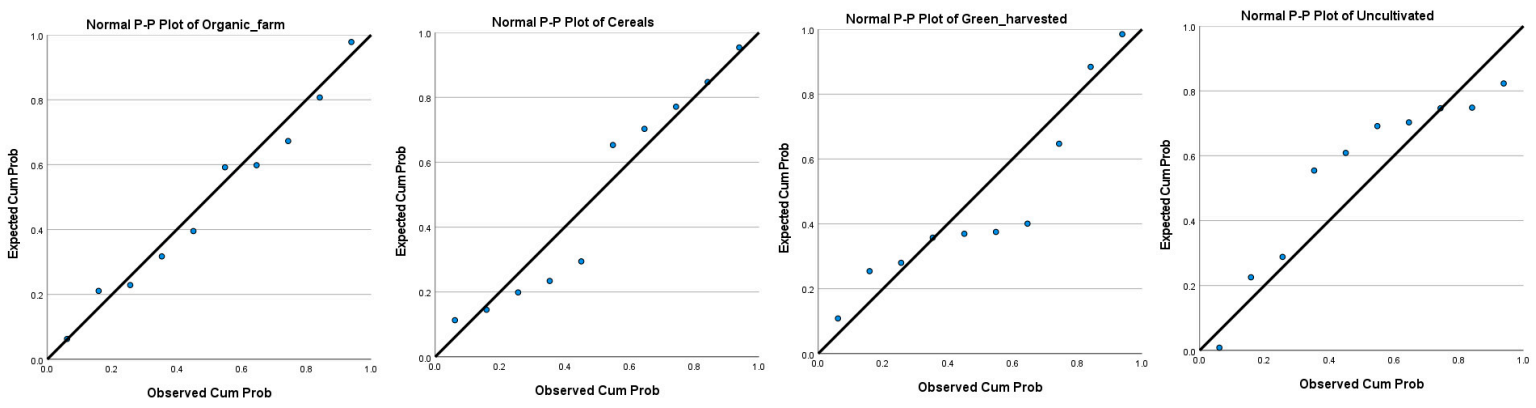

Figure 5. P-P plot for each analyzed variable.

Overall, the model is very representative $\left(R^{2}\right.$ is 0.971$)$. The variation of the independent variable (cereals, green_harv, uncultivated) explains $97 \%$ of the variation of the dependent variable (total cultivated land). The other percentages should be explained by other variables such as dried legumes and protein crops, tuberous and root plants, industrial crops, vegetables, and permanent crops.

The ANOVA test confirms the before mentioned findings because $\mathrm{F}>\mathrm{F}$ crit and Sig $\mathrm{F}<0.01$ (Table 3). 
The $\mathrm{R}$ coefficient is 0.99 , bigger than the minimum limit of 0.95 as the model to be reliable. The T-test marginal significance level for estimated coefficients is less than only 0.01 for the cereals' coefficient, meaning that this coefficient is very well estimated, and the others could be better estimated.

Following the statistical test $\mathrm{F}$, the resulting coefficient for cereals variable is 2.4 , with a probability of guaranteeing results (Prob) of 0.01 (less than the sensitivity threshold of $0.05)$ so this variable's coefficient is well estimated. The coefficient for green_harv variable is 0.8 with $95 \%$ likelihood, it will be found in the interval [-1.1:2.7]. The coefficient for the uncultivated variable is -6.06 , with $95 \%$ likelihood, it will be found in the interval [-16.16; 4.04]. The intercept value was estimated to be $86,081.9$ with $95 \%$ likelihood, it will be found in the interval $[-52.640 ; 224.804]$ (Table 4).

Table 4. Coefficients estimation and collinearity diagnostics.

\begin{tabular}{|c|c|c|c|c|c|c|c|c|c|c|}
\hline \multicolumn{11}{|c|}{ Coefficients $^{a}$} \\
\hline \multirow{2}{*}{ Model } & \multirow{2}{*}{\multicolumn{2}{|c|}{$\begin{array}{l}\text { Unstandard. Coeff. } \\
\text { B }\end{array}$}} & \multirow[b]{2}{*}{ Std. Err. } & \multirow{2}{*}{$\begin{array}{l}\text { Standard. } \\
\text { Coeff. } \\
\text { Beta }\end{array}$} & \multirow[t]{2}{*}{$\mathbf{T}$} & \multirow[t]{2}{*}{ Sig } & \multicolumn{2}{|c|}{$\begin{array}{l}95.0 \% \text { Confidence } \\
\text { Interval for B }\end{array}$} & \multicolumn{2}{|c|}{$\begin{array}{l}\text { Collinearity } \\
\text { Statistics }\end{array}$} \\
\hline & & & & & & & Lower & Upper & Tolerance & VIF \\
\hline \multirow{4}{*}{1} & (Constant) & $86,081.95$ & $56,692.8$ & & 1.52 & 0.18 & $-52,640.4$ & $224,804.3$ & & \\
\hline & Cereals & 2.384 & 0.319 & 0.751 & 7.47 & 0.00 & 1.603 & 3.164 & 0.477 & 2.09 \\
\hline & Green_harv & 0.807 & 0.790 & 0.130 & 1.02 & 0.34 & -1.125 & 2.739 & 0.296 & 3.37 \\
\hline & Uncultiv. & -6.061 & 4.131 & -0.180 & -1.46 & 0.19 & -16.168 & 4.046 & 0.319 & 3.14 \\
\hline \multicolumn{11}{|c|}{ Coefficient Correlations $^{\text {a }}$} \\
\hline \multicolumn{4}{|c|}{ Model } & Uncultiv. & Cereals & & \multicolumn{4}{|c|}{ Green_harv } \\
\hline \multirow{6}{*}{1} & \multicolumn{3}{|c|}{ Uncultivated } & 1.000 & 0.249 & & \multicolumn{4}{|c|}{0.646} \\
\hline & \multirow[t]{3}{*}{ Correlations } & \multicolumn{2}{|c|}{ Cereals } & 0.249 & 1.000 & & \multicolumn{4}{|c|}{-0.357} \\
\hline & & \multicolumn{2}{|c|}{ Green_harv } & 0.646 & -0.357 & & \multicolumn{4}{|c|}{1.000} \\
\hline & & \multicolumn{2}{|c|}{ Uncultivated } & 17.061 & 0.329 & & \multicolumn{4}{|c|}{2.106} \\
\hline & \multirow[t]{2}{*}{ Covariances } & \multirow{2}{*}{\multicolumn{2}{|c|}{$\begin{array}{c}\text { Cereals } \\
\text { Green_harv }\end{array}$}} & 0.329 & 0.102 & & \multirow{2}{*}{\multicolumn{4}{|c|}{$\begin{array}{c}-0.090 \\
0.623\end{array}$}} \\
\hline & & & & 2.106 & -0.090 & & & & & \\
\hline \multicolumn{11}{|c|}{ Collinearity Diagnostics ${ }^{a}$} \\
\hline Model & Dimension & Eigenvalue & $\begin{array}{l}\text { Condition } \\
\text { Index }\end{array}$ & \multicolumn{7}{|c|}{$\begin{array}{c}\text { Variance Proportions } \\
\text { Green_harv }\end{array}$} \\
\hline \multirow{4}{*}{1} & 1 & 3.748 & 1.000 & 0.00 & 0.00 & & \multicolumn{2}{|c|}{0.00} & \multicolumn{2}{|c|}{0.00} \\
\hline & 2 & 0.232 & 4.021 & 0.00 & 0.00 & & \multicolumn{2}{|c|}{0.18} & \multicolumn{2}{|c|}{0.02} \\
\hline & 3 & 0.017 & 15.020 & 0.00 & 0.65 & & 0 . & & 0.13 & \\
\hline & 4 & 0.003 & 33.693 & 1.00 & 0.35 & & 0 . & & 0.85 & \\
\hline
\end{tabular}

a Dependent Variable: Organic_farm.

The equation of the regression model is presented below:

Total land organic farming $=86,081.9+2.4 \times$ Cereals $+0.8 \times$ Green_harv $-6.06 \times$ Uncultivated land

The "Collinearity Diagnostics" shows us the Eigenvalues of the scaled, un-centered cross-products matrix; the condition indexes; and the variance proportions. The lowest Eigenvalue (0.017), show that Cereals and Green_harv variables have some variance proportions ( 0.65 and 0.61$)$ for Dimension 3 , which means that $65 \%$ of the variance of the b-value for Cereals and $61 \%$ of the variance of the b-value for Green_harv were associated with the Eigenvalue 3 (the smallest Eigenvalue). This result suggests that there might be some dependency between these two variables. The largest VIF (3.37) is for Green_harv, but it is not greater than 10, so it is within tolerance. The corresponding Tolerance Statistic for Green_harv (0.29), which is not below 0.1, means that it is within tolerance. The average VIF is $2.87((2.098+3.373+3.138) / 3=2.87)$, which is not substantially greater than 1 . The average Tolerance Statistic is 0.35 , which is not below 0.2. The VIF and Tolerance Statistics show 
that there is no multicollinearity in this data, but not very important collinearity exists between two of the predictors (Cereals and Green_harv). This collinearity is not sensible as to remove one of the variables from the proposed model.

Thus, the alternative hypothesis, H1, is accepted. H1 stands that organic farming is represented especially by cereals and green harvested plants. Organic farming loses a lot of profit because of the uncultivated land. The farmers should use all the land available and plant organically and adequate management in this field is required.

In the context of supply chains in Romanian agriculture, the phenomenon of integration is manifested more in the sphere of vegetable and animal production, vegetable residues, or even important parts of plant production being intended to feed meat animals, in particular, in the form of fodder. The propagating material is the subject of reproduction only in model greenhouses or farms that comply with high standards in the preservation and improvement of the quality of the genetic background. Storage and distribution are the responsibility of economic agents affiliated with the agri-food production sector, ex Danone, although a good trend is the appearance of high-capacity silos in the vicinity of crops, in order to reduce transport costs, or as a buffer warehouse in addition to the major shipping routes (e.g., Stanca, Braila) or rail transport (e.g., Boromir, Buzau). Fragmentation of the supply chain by the disappearance of research centers, seeds producers (agrosems; SCDL Buzau a rare and happy exception) as well as the lack of storage and raw processing capacities (drying, treatment for preservation, chopping/grinding, etc.) lead to the strong manifestation of the seasonality of production and price scissors at the expense of small agricultural entrepreneurs. The peculiarities of the Romanian agricultural system in the field of plant production and specific supply chains will be the subject of further research.

The private agricultural system dedicated to vegetable production is marked by two phenomena with economic impact: that of the procedure of concession of land in the public domain to private entrepreneurs and that of the amalgamation of individual properties of small size and dispersed in large agricultural holdings through the lease agreement. It stipulates lump sums and/or products in favor of the agricultural owner. A sharp trend, but of low economic impact, is the small biologically certified holding that produces extensively small quantities of products sought for export such as truffles, nuts, berries, herbs, and medicinal plants. However, the social role of this type of business is high, being in many cases the only source of income of a family.

\section{Discussion}

The United Nations 2030 Agenda for Sustainable Development includes as an important goal the sustainable acquisitions, based on specific programs able to measure the price-performance-impact on the environment balance regarding raw materials, services, products, technologies, etc. GPP and IPP have an important impact on sustainability, reducing the environmental footprint. GPP itself is also based on innovative policies, strategies, and acquisition model, following the type of product or service. Furthermore, eco-labels were designed to sustain the GPP process to gain social, health, environmental, and ethical sustainability. For a clear understanding and a good implementation of GPP international standards like GECA were set. These types of standards represent guidelines and restrictions regarding pollution management in different fields such as construction, transportation, services, tourism, health, education having a positive impact on the eco-environment (Figure 6). 


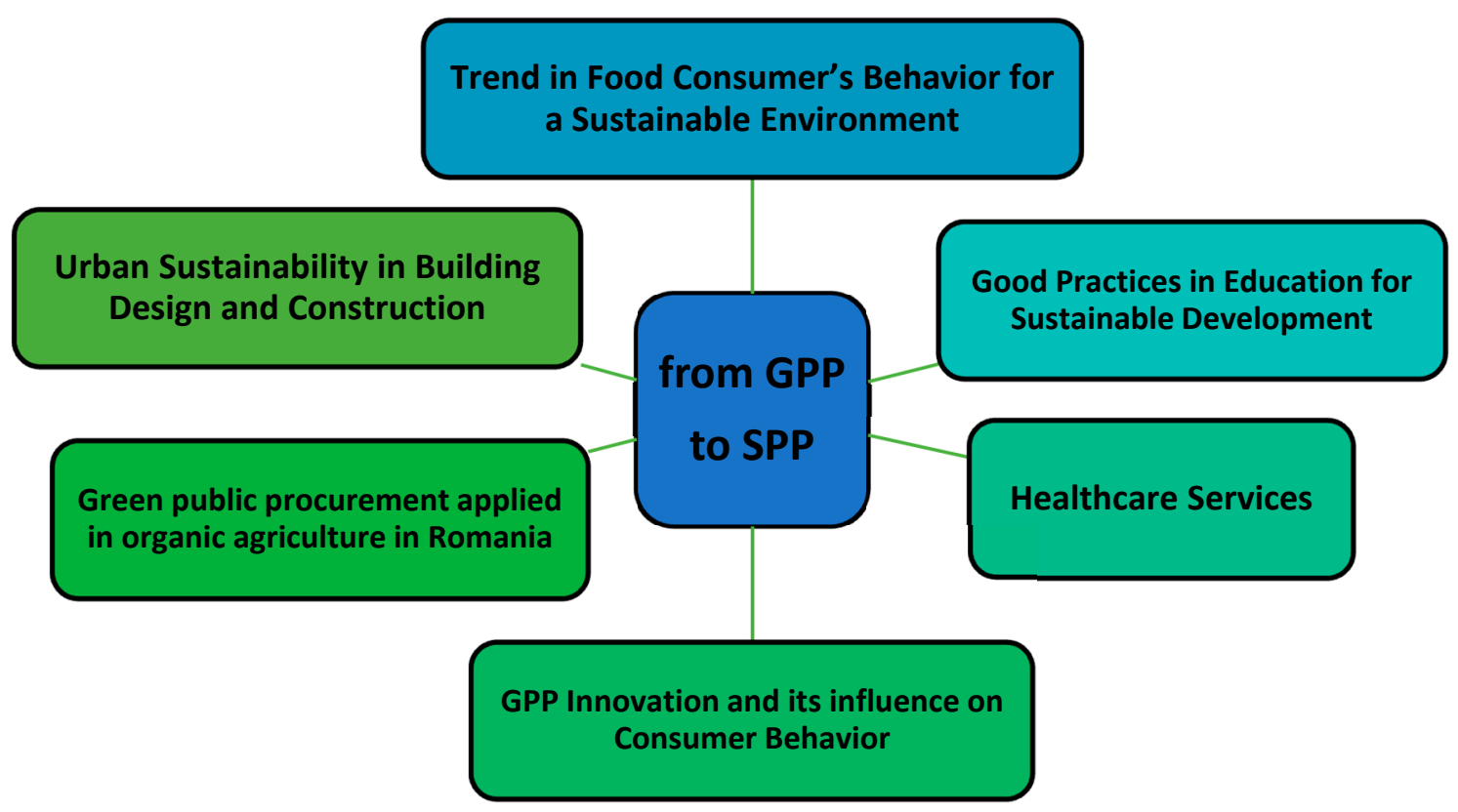

Figure 6. Integrated application of GPP and sustainable public procurement (SPP) in equilibrium between economic, social, and environmental pillars.

We chose organic farming in Romania as a case study because the EU Action Plan for organic farming comes with new regulations in the future which recommends initiatives to support consumer confidence, support for increased export opportunities for organic food, development of electronic import certification systems, encouraging the use of organic food in schools through GPP. Currently, over $40 \%$ of the land in Romania is worked by $0.56 \%$ of farmers, in farms larger than 300 hectares. Approximately the same area is worked by $97 \%$ of farmers (about 795,000 farmers), in small farms, under 50 hectares. This can be good from the perspective of ensuring sustainable local procurement and green agriculture. This approach can lead to foods that are better for the health and well-being of communities. However, these small, subsistence farms will not be able to exist if they do not associate. Therefore, they will have to support agriculture in terms of green procurement, supply chain management, circular economy; they will need legislation in this field and especially these measures will have to be implemented. Environmental protection is a major goal of organic farming. Agricultural production combines the best environmental practices, maintains biodiversity, and contributes to the conservation of natural resources, supports animal husbandry and welfare, and especially respects consumers' preferences for healthy products. The challenge of the sector is to ensure the constant increase of the supply and the demand of the consumers, keeping their confidence in quality. Legislation, the evolution of society played an important role. Research and innovation are tools for overcoming the challenges posed by ecological norms.

Building eco-houses, sustainable refurbishment of empty homes, and the use of eco-friendly construction materials and products have a positive impact on ecological footprints, such as $\mathrm{CO}_{2}$ emissions, dust emissions, noise stress, and energy consumption, with a positive impact on health. The latest trend in sustainable landscape architecture is the establishment of horticultural crops on the roofs of public buildings in the center of cities to fix $\mathrm{CO}_{2}$ and other substances with carcinogenic potential in the atmosphere, maintain a constant micro-climate inside the building and support several species of pollinators such as insects and birds. Supporting this type of activity requires minimal public allocations with seeds and fertilizers, since species resistant to drought, pollution and adapted to the local biosphere will be chosen. An incentive factor is the dissemination of ideas associated with maintaining ecological balance in large urban agglomerations through recreational and formative activities with small groups of students in such gardens in the vicinity of 
educational centers. In addition, employees in office buildings that have green spaces on the roof can benefit from a seating space and table without having to move to parks or restaurants far away from work.

It is recommended for HEIs to design and implement GPP planning and have quantitative and qualitative criteria for monitoring the GPP program: choosing the lowest price is not always a valid criterion; sometimes analyzing the life cycle cost of the green products/services procures will emphasize that the most expensive items can save on long-term costs. If most of the universities will implement SPP, a majority of organizations would follow on SPP implementation as the future organization's employees are today's students. Another important recommendation is to follow the Minimum Environmental Criteria. Improved communication regarding leadership engagement and sustainable routine practices are also important factors in gaining SPP in HEIs. Considering that, one might think that the basis of the problem lies in the costs. If one compared the effort implied with the short-term benefits associated, sustainability would not be a priority. Nevertheless, it is imperative to think long term. The reasons that lead people to think in the short term are very much associated with the financial conditions of families. Sometimes it is cheaper to buy than to reuse resources. Besides, there is no concern with the environment (included waste or residuals resources) when the associated costs are too high to bear. It means that people might be aware of the consequences but unwilling to change. This is a challenge that involves the underlying principles that drive humanity, as well as personal values.

Given the difficulty of evaluating principles, which involve the specificity of the cultural dimension of each community, the following question was raised: is it possible to overcome the existing barriers in the consumption paradigm? To answer this question, this work focused on identifying the main barriers involved in the paradigm of consumerism versus sustainability mainly through the lenses of cost in the implementation of sustainability.

Public procurement is not just an administrative procedure, but a significant actor in the market. Globally, $12 \%$ of GDP is spent on public procurement according to the World Bank [85], with as much as 20-25\% in countries like Switzerland or the Netherlands. Thus, green practices in public procurement have the potential to make a truly large impact on environmental sustainability, provided that they are correctly used. Sustainability is not an individual task but a task for all of us. It is necessary to seek economic and social balance, as well as preserving the environment. It is also possible to bring together short and long terms objectives.

\section{Conclusions}

SPP can be achieved mainly through GPP and IPP, as a branch of GPP. The center of this research concerns the relevance of implementing GPP. In this regard, we highlighted some barriers that can be found in implementation and suggested a five-step plan that can be done before implementing any change.

Our research emphasizes, by analyzing 80 articles by the PRISMA method, the role of GPP in educating and changing consumer behavior, that has positive consequences on sustainability in different sectors of activity. Thus, educating towards "green" attitudes and competencies significantly impacts their willingness and ability to act according to GPP principles. Furthermore, specific legislation, policies, and procedures have to be implemented concerning each main area of public procurement interest: construction, healthcare, and food to have a concerted and concentrated impact. However, even more important is the use of GPP in driving sustainable innovation through IPP. The ability of governments to virtually create a market for specific innovative products, solutions, and ideas is decisive for the development of radical innovations.

The role of governments should be to stimulate the creation of environmentally friendly services and products by allocating their purchasing might towards those by relying more on Social ROI and less on traditional monetary measures. As it was observed from the case study of organic farming in Romania, organic farming operators have 
evolved only when society got involved for them: there were subsidies for land users, for the acquisition of raw materials, product promotion, etc. The weaknesses in the agrifood sector are the disorganization in management, as evidenced by large uncultivated territories and small investments for certain types of vegetables.

State intervention in agriculture is limited by the dominant form of ownership in Romanian agriculture, namely the private one. However, the State can provide subsidies directed to the type of investment (the foundation of culture, mechanization, fertilizer administration, weeding, according to the technological file), environmental taxes can be calibrated according to the certification of the culture (biological/ecological), and the ease of agricultural credit for certain investments and the proactive surveillance of the insurance sector in agriculture or the supplementation of the insurance fund can be implemented. Local Agricultural Consulting Directorates (ANCA) can provide the necessary documentation for the establishment and certification of organic production, financial advice from the granting to the completion of the investment plan. Local authorities can stimulate domestic producers of machinery for agriculture and food production by subsidizing production costs, facilitating fairs and exhibitions, there can be issued green certificates for consumption in green agriculture in the sector of energy production.

Managers of organically certified farms should be encouraged to participate in international agricultural fairs and exhibitions in order to benefit from the expertise of other countries in the promotion of green technologies. Graduates of agricultural technical education must benefit from training courses in research and production farms, where they can apply their new green-oriented knowledge acquired at school. Alternative forms of contractual work in agriculture due to seasonality and uneven distribution of the available and skilled labor force in agriculture by organizing shuttles, relocating the families of agricultural workers in decent conditions, and integrating them to the higher levels of the agricultural production chain should be encouraged.

For GPP to evolve into SPP it is necessary to overcome certain barriers, as we identified in our study, in five steps: understand long-term population trends; learn more about the specificities of each city or urban area; think about everything that is important and make a plan; involve all stakeholders in the implementation of the plan; use measures to evaluate the results and update the initial plan.

\section{Limitations and Future Research Suggestions}

Although we studied a large sample of articles, these were exclusively published in the Scopus and Web of Science databases. We could not cover other databases, due to the vastness of the field. In future research, we would analyze points of view from transdisciplinary areas to increase GPP and B2B capacity to operate at a transnational level, share ideas, and develop the best practices and methods. Future research should investigate whether GPP, through organizational sustainability practices, can shape operational environmental sustainability and sustainable organizational culture.

Author Contributions: Conceptualization, R.B.-M.-T. (Rocsana Bucea-Manea-T,oniș) and V.-E.S.; methodology, R.B.-M.-T. (Rocsana Bucea-Manea-T,oniș) and C.B.; software, R.B.-M.-T. (Rocsana Bucea-Manea-Toniș); validation, R.B.-M.-T. (Radu Bucea-Manea-Toniș), O.M.D.M.; formal analysis, M.B.; investigation, R.B.-M.-T. (Rocsana Bucea-Manea-Tonis), V.-E.S.; resources, R.B.-M.-T. (Rocsana Bucea-Manea-Tonis, , O.M.D.M., M.B., D.I. and C.B.; data curation, R.B.-M.-T. (Radu Bucea-ManeaTonis); writing —original draft preparation, R.B.-M.-T. (Rocsana Bucea-Manea-Toniș) and V.-E.S.; writing-review and editing, R.B.-M.-T. (Rocsana Bucea-Manea-Toniș), O.M.D.M, and V.-E.S.; visualization, C.B.; supervision, R.B.-M.-T. (Rocsana Bucea-Manea-Țoniș), M.B.; project administration, R.B.-M.-T. (Rocsana Bucea-Manea-Tonis,). All authors have read and agreed to the published version of the manuscript.

Funding: This research received no external funding.

Conflicts of Interest: The authors declare no conflict of interest. 


\section{References}

1. Roehrich, J.K.; Hoejmose, S.; Overland, V. Driving green supply chain management performance through supplier selection and value internalization: A self-determination theory perspective. Int. J. Oper Prod. Manag. 2017, 37, 489-509. [CrossRef]

2. Farooque, M.; Zhang, A.; Thürer, M.; Qu, T.; Huisingh, D. Circular supply chain management: A definition and structured literature review. J. Clean. Prod. 2019, 228, 882-900. [CrossRef]

3. Moraga, G.; Huysveld, S.; Mathieux, F.; Blengini, G.A.; Alaerts, L.; Van Acker, K.; de Meester, S.; Dewulf, J. Circular economy indicators: What do they measure? Resour. Conserv. Recycl. 2019, 146, 452-461. [CrossRef] [PubMed]

4. Marrucci, L.; Daddi, T.; Iraldo, F. The integration of circular economy with sustainable consumption and production tools: Systematic review and future research agenda. J. Clean. Prod. 2019, 240. [CrossRef]

5. Neto, B. Analysis of sustainability criteria from European public procurement schemes for food services. Sci. Total Environ. 2019, 704, 135300. [CrossRef] [PubMed]

6. Pircher, B. EU public procurement policy: The economic crisis as trigger for enhanced harmonization. J. Eur. Integr. 2019, 42, 509-525. [CrossRef]

7. European Commission. 2020-EU GPP Criteria. Available online: https:/ /ec.europa.eu/environment/gpp/eu_gpp_criteria_en htm (accessed on 1 September 2020).

8. European Commission. Green and Sustainable Public Procurement. Available online: https://ec.europa.eu/environment/gpp/ versus_en.htm\#: \{\{:text=Sustainable\%20Public\%20Procurement $\% 20(\mathrm{SPP}) \% 20$ is, all $\% 20$ stages $\% 20$ of $\% 20$ the $\% 20$ project (accessed on 1 September 2020).

9. Trindade, P.C.; Antunes, P.; Partidário, P. SPP Toolbox: Supporting Sustainable Public Procurement in the Context of SocioTechnical Transitions. Sustainability 2018, 10, 67. [CrossRef]

10. Appolloni, A.; D'Amato, A.; Cheng, W. Is public procurement going green? Experiences and open Issues. In The Applied Law and Economics of Public Procurement; Piga, G., Treumer, S., Eds.; Routledge: Abingdon, UK, 2013; pp. 111-132.

11. Coppola, M.A.; Appolloni, A.; Piga, G. Implementation of Green Considerations in Public Procurement-A mean to promote sustainable development. In Green Public Procurement Strategies for Environmental Sustainability; Shakya, R.K., Ed.; IGI Global: Roma, Italy, 2019; pp. 23-44.

12. Cheng, W.; Appollonia, A.; D'Amato, A.; Zhu, Q. Green Public Procurement, Missing Concepts and Future Trends-A Critical Review. J. Clean. Prod. 2018, 176, 770-784. [CrossRef]

13. Litardi, I.; Fiorani, G.; Alimonti, D.; Appolloni, A. Green public procurement as a leverage for sustainable development documental: Analysis of 80 practices in European Union. In Green Public Procurement Strategies for Environmental Sustainability; Shakya, R.K., Ed.; IGI Global: Hershey, PA, USA, 2019; pp. 59-78. [CrossRef]

14. Hazen, B.T.; Mollenkopf, D.A.; Wang, Y. Remanufacturing for the circular economy: An examination of consumer switching behavior. Bus. Strateg. Environ. 2017, 26, 451-464. [CrossRef]

15. Patrucco, A.S.; Luzzini, D.; Ronchi, S. Research perspectives on public procurement: Content analysis of 14 years of publications in the journal of public procurement. J. Public Procure. 2017, 17, 229-269. [CrossRef]

16. Grandia, J.; Voncken, D. Sustainable Public Procurement: The Impact of Ability, Motivation, and Opportunity on the Implementation of Different Types of Sustainable Public Procurement. Sustainability 2019, 11, 5215. [CrossRef]

17. European Commission. GPP National Action Plans. Available online: https://ec.europa.eu/environment/gpp/action_plan_en. htm (accessed on 1 September 2020).

18. Lindström, H.; Lund, S.; Marklund, P.-O. How green public procurement can drive conversion of farmland: An empirical analysis of an organic food policy. Ecol. Econ. 2020, 172, 106622. [CrossRef]

19. Elkington, J. 25 Years ago I coined the Phrase "Triple Bottom Line". Here's Why It's Time to rethink It. Harv. Bus. Rev. 2018, 25, $2-5$.

20. Sustainable Development Goals. Available online: https://www.un.org/sustainabledevelopment/sustainable-developmentgoals (accessed on 1 September 2020).

21. Stoffel, T.; Cravero, C.; La Chimia, A.; Quinot, G. Multidimensionality of sustainable public procurement (SPP)—Exploring Concepts and effects in Sub-Saharan Africa and Europe. Sustainability 2019, 11, 6352. [CrossRef]

22. Stenmarck, A.; Jensen, C.; Quested, T.; Moates, G. Estimates of European Food Waste Levels; Report from the FUSIONS Project; European Commission (FP7), Coordination and Support Action-CSA: Luxembourg, 2016; ISBN 978-91-88319-01-2.

23. Estratégia Nacional e Plano de Ação de Combate ao Desperdício Alimentar; Proposta Elaborada pela Comissão Nacional de Combate ao Desperdício Alimentar. (CNCDA) em Conformidade com o Despacho n. ${ }^{\circ}$ 14202-B/2016, de 25 Novembro; Comissão Nacional de Combate ao Desperdício Alimentar; (CNCDA): Lisbon, Portugal, 2017.

24. Combater o Desperdício Alimentar. Uma Responsabilidade do Produtor ao Consumidor; Concertação, Sinergia, Envolvimento. Despacho n. ${ }^{\circ}$ 14202-B/2016, publicado no DR, 2. ${ }^{a}$ série, N. ${ }^{\circ} 227$, de 25 de novembro de 2016; Comissão Nacional de Combate ao Desperdício Alimentar; (CNCDA): Lisbon, Portugal, 2016.

25. De Laurentis, V.; Caldeira, C.; Sala, S. No time to waste: Assessing the performance of food waste prevention actions. Resour. Conserv. Recycl. 2020, 161, 104946. [CrossRef] 
26. Laschkolnig, A.; Habl, C.; Renner, A.T.; Bobek, J. EU Platform on Food Losses and Food Waste Terms of Reference (ToR); European Commission, Directorate-General for Health and Food Safety. Study on Big Data in Public Health, Telemedicine and Healthcare: Final Report. 2016. Available online: https:/ / ec.europa.eu/health/sites/health/files/ehealth/docs/bigdata_report_ en.pdf (accessed on 1 September 2020).

27. European Commission [EU]. EU Actions against Food Waste; European Commission: Luxembourg, 2018; Available online: https:/ / ec.europa.eu/food/safety / food_waste/eu_actions_en (accessed on 1 September 2020).

28. European Commission [EU]. Food Waste Monitoring-Update. EU Platform on Food Losses and Food Waste. 2018. Available online: https:/ / ec.europa.eu/food/sites/food/files/safety/docs/fw_eu-platform_20181206_flw_pres-03.pdf (accessed on 1 September 2020).

29. Goosens, Y.; Wegner, A.; Schmidt, T. Sustainability assessment of food waste prevention measures: Review of existing evaluation practices. Front. Sustain. Food Syst. 2019, 3, 90. [CrossRef]

30. Zeinstra, G.; Haar, S.V.D.; Bergen, G.V. Drivers, barriers and interventions for food waste behaviour change: A food system approach. Food Biobased Res. 2020. [CrossRef]

31. van Geffen, L.; van Herpen, É.; van Trijp, H. Quantified Consumer Insights on Food Waste. Pan-European Research for Quantified Consumer Food Waste Understanding. Available online: http://eu-refresh.org/quantified-consumer-insights-food-waste (accessed on 1 September 2020).

32. Commission Delegated Decision; 2019/1597; Directive 2008/98/EC of the European Parliament: Brussels, Belgium, $2019 ;$ p. 77.

33. David, A.; Thangavel, Y.D.; Sankriti, R. Recover, Recycle and Reuse: An Efficient Way to Reduce the Waste. Int. J. Mech. Prod. Eng. Res. Dev. 2019, 9, 31-42.

34. Ahsan, K.; Rahman, S. Green public procurement implementation challenges in Australian public healthcare sector. J. Clean. Prod. 2017, 152, 181-197. [CrossRef]

35. Chiarini, A.; Opoku, A.; Vagnoni, E. Public healthcare, practices and criteria for a sustainable procurement: A comparative study between UK and Italy. J. Clean. Prod. 2017, 162, 391-399. [CrossRef]

36. Uyarra, E.; Zabala-Iturriagagoitia, J.; Flanagan, K.; Magro, E. Public procurement, innovation and industrial policy: Rationales, roles, capabilities and implementation. Res. Policy 2020, 49, 103844. [CrossRef]

37. Boon, W.; Edler, J. Demand, challenges, and innovation. Making sense of new trends in innovation policy. Sci. Public Policy 2018, 45, 435-447. [CrossRef]

38. Uyarra, E.; Flanagan, K.; Magro, E.; Zabala-Iturriagagoitia, J.M. Anchoring the innovation impacts of public procurement to place: The role of conversations. Environ. Plan. 2017, 35, 828-848. [CrossRef]

39. Meehan, J.; Menzies, L.; Michaelides, D.R. The long shadow of public policy; Barriers to a value-based approach in healthcare procurement. J. Purch. Supply Manag. 2017, 23, 229-241. [CrossRef]

40. Millera, F.A.; Lehouxb, P. The innovation impacts of public procurement offices: The case of healthcare procurement. Res. Policy 2020, 49, 104075. [CrossRef]

41. Vatalis, K.I.; Manoliadis, O.G.; Mavridis, D.G. Project Performance Indicators as an Innovative Tool for Identifying Sustainability Perspectives in Green Public Procurement. Procedia Econ. Financ. 2012, 1, 401-410. [CrossRef]

42. Ghisetti, C. Demand-pull and environmental innovations: Estimating the effects of innovative public procurement. Technol. Forecast. Soc. Chang. 2017, 125, 178-187. [CrossRef]

43. Ghisetti, C.; Quatraro, F. Green technologies and environmental productivity: A cross-sectoral analysis of direct and indirect effects in Italian regions. Ecol. Econ. 2017, 132, 1-13. [CrossRef]

44. Ghosh, M. Determinants of green procurement implementation and its impact on firm performance. J. Manuf. Technol. Manag. 2019. [CrossRef]

45. Qiansong, Z.; Jieyi, P.; Yisa, J.; Taiwen, F. The impact of green supplier integration on firm performance: The mediating role of social capital accumulation. J. Purch. Supply Manag. 2020, 26, 100579.

46. Obwegeser, N.; Müller, S.D. Innovation and public procurement: Terminology, concepts, and applications. Technovation 2018, 74, 1-17. [CrossRef]

47. Teixeira, C.R.B.; Assumpção, A.L.; Correa, A.L.; Savi, A.F.; Prates, G.A. The contribution of green logistics and sustainable purchasing for green supply chain management. Indep. J. Manag. Prod. 2018, 9, 1002-1026. [CrossRef]

48. De Giacomo, M.R.; Testa, F.; Iraldo, F.; Formentini, M. Does Green Public Procurement lead to Life Cycle Costing (LCC) adoption? J. Purch. Supply Manag. 2019, 25, 100500. [CrossRef]

49. Harrisa, K.; Divakarlaa, S. Supply chain risk to reward: Responsible procurement and the role of ecolabels. Procedia Eng. 2017, 180, 1603-1611. [CrossRef]

50. Qiang, T.; Jianlei, M.; Regina, B.; Lianbiao, C.; Ying, F.; Yu, L. Achieving grid parity of solar PV power in China-The role of Tradable Green Certificate. Energy Policy 2020, 144, 111681. [CrossRef]

51. International Organisation for Standardisation (ISO). Sustainable Procurement One Step Closer to an International Standard. Available online: http://www.iso.org/iso/home/news_index/news_archive/news.htm?refid=Ref1873 (accessed on 2 September 2020).

52. Ecolabel Index-GECA. Available online: http://www.ecolabelindex.com/ecolabel/good-environmental-choice-australia (accessed on 2 September 2020). 
53. Good Environmental Choice Australia. Our Standards. Available online: http://www.geca.org.au/standards/ (accessed on 2 September 2020).

54. Rainville, A. Standards in Green Public Procurement-A framework to enhance innovation. J. Clean. Prod. 2017, 167, 1029-1037. [CrossRef]

55. Bleda, M.; Chicot, J. The role of public procurement in the formation of markets for innovation. J. Bus. Res. 2018, 107, 186-196. [CrossRef]

56. Vijay, P.O.; Sanjib, P.; Joydeep, G. Recycling carbon tax for inclusive green growth: A CGE analysis of India. Energy Policy 2020, 144, 111708. [CrossRef]

57. Czarnitzki, D.; Hünermund, P.; Moshgbar, N. Public Procurement of Innovation: Evidence from a German Legislative Reform. Int. J. Ind. Organ. 2020, 71, 102620. [CrossRef]

58. Wang, F.; Wang, K.; Wang, L. An examination of a city greening mega-event. Int. J. Hosp. Manag. 2018, 77, 538-548. [CrossRef]

59. Ceranic, B.; Markwell, G.; Dean, A. Too many empty homes, too many homeless-A novel design and procurement framework for transforming empty homes through sustainable solutions. Energy Procedia 2017, 111, 558-567. [CrossRef]

60. Brusselaers, J.; Van Huylenbroeck, G.; Buysse, J. Green Public Procurement of Certified Wood: Spatial Leverage Effect and Welfare Implications. Ecol. Econ. 2017, 135, 91-102. [CrossRef]

61. Palander, T.; Haavikko, H.; Kärhä, K. Towards sustainable wood procurement in forest industry-The energy efficiency of larger and heavier vehicles in Finland. Renew. Sustain. Energy Rev. 2018, 96, 100-118. [CrossRef]

62. Low, S.; Ullah, F.; Shirowzhan, S.; Sepasgozar, S.M.E.; Lee, C.L. Smart Digital Marketing Capabilities for Sustainable Property Development: A Case of Malaysia. Sustainability 2020, 12, 5402. [CrossRef]

63. Bohari, A.A.M.; Skitmore, M.; Xia, B.; Teo, M.; Khalil, N. Key stakeholder values in encouraging green orientation of construction procurement. J. Clean. Prod. 2020, 270, 122246. [CrossRef]

64. Yu, A.T.W.; Yevu, S.K.; Nani, G. Towards an integration framework for promoting electronic procurement and sustainable procurement in the construction industry: A systematic literature review. J. Clean. Prod. 2020, 250, 119493. [CrossRef]

65. Schestak, I.; Spriet, J.; Styles, D.; Prysor Williams, A. Emissions down the drain: Balancing life cycle energy and greenhouse gas savings with resource use for heat recovery from kitchen drains. J. Environ. Manag. 2020, 271, 110988. [CrossRef]

66. Macke, J.; Sarate, J.A.R.; de Atayde Moschen, S. Smart sustainable cities evaluation and sense of community. J. Clean. Prod. 2019, 239, 118103. [CrossRef]

67. Filho, W.L.; Skouloudis, A.; Londero Brandli, L.; Lange Salvia, A.; Veiga Avila, L.; Rayman-Bacchus, L. Sustainability and procurement practices in higher education institutions: Barriers and drivers. J. Clean. Prod. 2019, 231, 1267-1280. [CrossRef]

68. O'Donoghue, R. Situated Learning in Relation to Human Conduct and Social-Ecological Change. In Schooling for Sustainable Development in Africa; LotzSisitka, H., Shumba, O., Lupele, J., Wilmot, D., Eds.; Springer: Berlin, Germany, 2016 ; pp. $25-38$.

69. Pacheco-Blanco, B.; Bastante-Ceca, J.M. Green public procurement as an initiative for sustainable consumption. An exploratory study of Spanish public universities. J. Clean. Prod. 2016, 133, 648-656. [CrossRef]

70. Vapa-Tankosić, J.; Ignjatijević, S.; Kiurski, J.; Milenković, J.; Milojević, I. Analysis of Consumers' Willingness to Pay for Organic and Local Honey in Serbia. Sustainability 2020, 12, 4686. [CrossRef]

71. Fuentes-Bargues, L.J.; Ferrer-Gisbert, P.S.; Gonzalez-Cruz, M.C. Analysis of Green Public Procurement of Works by Spanish Public Universities. Int. J. Environ. Res. Public Health 2018, 15, 1888. [CrossRef] [PubMed]

72. Delmonico, D.; Jabbour, C.J.C.; Pereira, S.C.F.; Jabbour, A.B.L.D.S.; Renwick, D.S.; Thomé, A.M.T. Unveiling barriers to sustainable public procurement in emerging economies: Evidence from a leading sustainable supply chain initiative in Latin America. Resour. Conserv. Recycl. 2018, 134, 70-79. [CrossRef]

73. Song, W.; Ming, X.; Liu, H.C. Identifying critical risk factors of sustainable supply chain management: A rough strength-relation analysis method. J. Clean. Prod. 2017, 143, 100-115. [CrossRef]

74. Chan, A.P.C.; Darko, A.; Olanipekun, A.O.; Ameyaw, E.E. Critical Barriers to Green Building Technologies Adoption in Developing Countries: The Case of Ghana. J. Clean. Prod. 2018, 172, 1067-1079. [CrossRef]

75. Liu, J.; Xue, J.; Yang, L.; Shi, B. Enhancing green public procurement practices in local governments: Chinese evidence based on a new research framework. J. Clean. Prod. 2019, 211, 842-854. [CrossRef]

76. Fang, H.; Wang, B.; Song, W. Analyzing the Interrelationships among Barriers to Green Procurement in Photovoltaic Industry: An Integrated Method. J. Clean. Prod. 2019, 249, 119408. [CrossRef]

77. Wade, A.; Sinha, P.; Drozdiak, K.; Mulvaney, D.; Slomka, J. Ecodesign, Ecolabeling, and Green Procurement Policies-enabling more Sustainable Photovoltaics? In Proceedings of the IEEE 7th World Conference on Photovoltaic Journal Pre-Proof 34 Energy Conversion (WCPEC), Waikoloa Village, HI, USA, 10-15 June 2018; pp. 2600-2605.

78. Jensen, L. (Ed.) The Sustainable Development Goals Report; United Nations: New York, NY, USA, 2019; Available online: https: // unstats.un.org/sdgs/report/2019/The-Sustainable-Development-Goals-Report-2019.pdf (accessed on 2 September 2020).

79. Philips, M.; Schuler, E.R.; Alejandra, M. Groningen Leads the World. Available online: https://industrielinqs.nl/wp-content/ uploads /2019/10/Paris-is-not-enough.pdf (accessed on 2 September 2020).

80. Wang, J.; Zhang, Y.; Goh, M. Moderating the role of firm size in sustainable performance improvement through sustainable supply chain management. Sustainability 2018, 10, 1654. [CrossRef] 
81. Martek, I.; Hosseini, M.R.; Shrestha, A.; Edwards, D.J.; Durdyev, S. Barriers inhibiting the transition to sustainability within the Australian construction industry: An investigation of technical and social interactions. J. Clean. Prod. 2019, 211, 281-292. [CrossRef]

82. Shen, L.; Zhang, Z.; Zhang, X. Key factors affecting green procurement in real estate development: A China study. J. Clean. Prod. 2017, 153, 372-383. [CrossRef]

83. Shen, L.; Zhang, Z.; Long, Z. Significant barriers to green procurement in real estate development. Resour. Conserv. Recycl. 2017, 116, 160-168. [CrossRef]

84. Pentru Aprobarea Ghidului de Achiziţii Publice Verzi Care Cuprinde Cerinţele Minime Privind Protecţia Mediului Pentru Anumite Grupe de Produse şi Servicii ce se Solicită la Nivelul Caietelor de Sarcini. Available online: http:/ /anap.gov.ro/web/ wp-content/uploads/2018/11/ORDIN-Nr-1068-Achizitii-verzi.pdf (accessed on 2 September 2020).

85. Bosio, E.; Djankov, S. How Large is Public Procurement? Available online: https://blogs.worldbank.org/developmenttalk/howlarge-public-procurement (accessed on 2 September 2020). 